\title{
Tonotopic map of potassium currents in chick auditory hair cells using an intact basilar papilla
}

\author{
Anastasia A. Pantelias, Pablo Monsivais, Edwin W Rubel * \\ Virginia Merrill Bloedel Hearing Research Center and Department of Otolaryngology-Head and Neck Surgery, P.O. Box 357923 CHDD CD 176, \\ University of Washington, Seattle, WA 98195, USA
}

Received 3 July 1999; accepted 26 February 2001

\begin{abstract}
The avian basilar papilla is tonotopically organized such that hair cells along the sensory epithelium respond best to acoustic stimulation at differing frequencies. This specificity arises due to the mechanics of the cochlea itself and intrinsic electrical properties of the hair cells. Tall hair cells show membrane voltage oscillations in response to step current injection that may allow cells to act as electrical resonators, boosting the response at the resonant frequency. These oscillations and the underlying currents have been studied in enzymatically isolated cells. This study uses a whole chick (Gallus domesticus) basilar papilla preparation where the entire epithelium and its afferent connections are intact. With this preparation, a map of changes in potassium currents of tall hair cells was produced. All cells recorded from expressed two $\mathrm{K}^{+}$currents, a calcium-activated $\mathrm{K}^{+}$current, $I_{\mathrm{K}(\mathrm{Ca})}$, and a voltage-activated $\mathrm{K}^{+}$ current, $I_{\mathrm{K}}$. Also, apical cells expressed an inward rectifier $\mathrm{K}^{+}$current, $I_{\mathrm{IR}}$. The amplitude of total outward current increases in a gradient along the tonotopic axis. Pharmacological blockers were used to separate the outward $\mathrm{K}^{+}$currents. These experiments showed that both currents individually increase in magnitude along a gradient from apex to base. Finally, measurements of oscillation frequency in response to current steps suggest a discontinuous change in the electrical resonances at about $33 \%$ from the apex. This study demonstrates a new preparation to study the electrical properties of hair cells in more detail along the tonotopic axis of the chick basilar papilla. (C) 2001 Elsevier Science B.V. All rights reserved.
\end{abstract}

Key words: Potassium current; Basilar papilla; Hair cell physiology; Patch clamp

\section{Introduction}

An important function of the cochlea is to break down complex sounds into their constituent frequencies. To accomplish this task, hair cells at different regions of the cochlea are most sensitive to specific frequencies of acoustic stimulation. In birds, mammals and some reptiles, hair cells located at the apex of the cochlea best transduce low frequencies while cells located at the base best transduce high frequencies (von Békésy, 1960). This gradient in frequency selectivity is partly achieved through changes in the mechanical properties such as variation in the passive mechanical

\footnotetext{
* Corresponding author. Tel.: +1 (206) 543-8360; Fax: +1 (206) 616-1828; E-mail: rubel@u.washington.edu
}

properties of the basilar membrane (von Békésy, 1960) and length of hair cell bundles (Tilney and Saunders, 1983). In addition to mechanical variations along the cochlea, the hair cells of many amphibians (Lewis and Hudspeth, 1983; Pitchford and Ashmore, 1987), reptiles (Crawford and Fettiplace, 1981; Art and Fettiplace, 1987; Fuchs and Evans, 1988) and birds (Fuchs et al., 1988) are thought to be tuned as a result of intrinsic electrical properties which allow cells to act as electrical resonators. When depolarized by current injection, the hair cells of these animals exhibit damped, sinusoidal membrane voltage oscillations that arise from the intrinsic membrane conductances. This property of hair cells may act to boost responses to acoustic stimuli when the resonant frequency of the cell and the stimulus frequency are matched.

Electrical tuning in avian auditory hair cells has been studied previously in tall hair cells, which receive the 
majority of afferent endings. In contrast, short hair cells have a larger proportion of efferent endings (Tanaka and Smith, 1978; Fischer, 1992). In the basilar papilla, tall and short hair cells can be distinguished based on morphological criteria (Takasaka and Smith, 1971, 1978) and location within the papilla (Hirokawa, 1978; Fischer, 1992).

Tall hair cells show membrane properties and ionic conductances that differ depending on their location within the papilla. Three identified currents that contribute to the tonotopic variation in electrical resonance found in tall hair cells (Fuchs et al., 1988) are: a delayed rectifier $\left(I_{\mathrm{K}}\right)$; a $\mathrm{Ca}^{2+}$-activated $\mathrm{K}^{+}$current $\left(I_{\mathrm{K}(\mathrm{Ca})}\right)$; and an inward $\mathrm{Ca}^{2+}$ current (Fuchs and Evans, 1990; Fuchs et al., 1990). It has been shown that while the kinetics of the $\mathrm{Ca}^{2+}$ current do not change, there is a clear gradient in the magnitude of the current along the length of the papilla (Martinez-Dunst et al., 1997). This may, in turn, affect the magnitude of $I_{\mathrm{K}(\mathrm{Ca})}$. Previous work has also shown that there are basic pharmacological and kinetic differences between $I_{\mathrm{K}(\mathrm{Ca})}$ and $I_{\mathrm{K}} \cdot I_{\mathrm{K}(\mathrm{Ca})}$ has faster kinetics and can be blocked by 10 $\mathrm{mM}$ tetraethylammonium (TEA). In contrast, $I_{\mathrm{K}}$ has slower kinetics and can be blocked by $0.8 \mathrm{mM}$ 4-aminopyridine (4-AP) (Fuchs and Evans, 1990). It can be postulated that it is the differential distribution and magnitude of the $\mathrm{K}^{+}$currents that determine the resonant frequency of a hair cell.

The purpose of this study was to create a preparation useful for further investigating the physiological expression and tonotopic map of the outward $\mathrm{K}^{+}$currents in tall hair cells along the chick basilar papilla. While previous studies by Fuchs and colleagues were conducted on hair cells dissociated from identified regions of the papilla, our study used an intact basilar papilla preparation in which the entire sheet of sensory epithelium and afferent connections remain intact. This approach allowed greater resolution in the mapping of ionic currents along the papilla while avoiding the possible alteration of ion channel properties due to enzymatic dissociation. We found that across cells, the peak magnitude of the total outward $\mathrm{K}^{+}$currents follows an exponential rise, with as much as a 10 -fold increase in total current from apex to base. In addition, it was found that both $I_{\mathrm{K}}$ and $I_{\mathrm{K}(\mathrm{Ca})}$ individually increase in amplitude from apex to base. Recordings performed in current-clamp mode suggested that despite the gradients in outward current magnitude, the hair cells recorded from fell into one of two categories depending on their location. More apical cells showed voltage oscillations below 30 $\mathrm{Hz}$ while more basal cells showed oscillations above 120 $\mathrm{Hz}$, and a gradient of increasing oscillation frequency toward the base. Preliminary results were presented previously (Pantelias et al., 1998).

\section{Materials and methods}

\subsection{Preparation}

1-10 day old post-hatch White Leghorn chicks (Gallus domesticus) were used for these studies. By hatching, the response properties of the chick auditory system are nearly mature in every respect that has been studied except for the sensitivity to the highest frequencies (Saunders et al., 1973; Rebillard and Rubel, 1981; Tucci and Rubel, 1990). The majority of data were taken from 1-5 day old chicks and there were no apparent differences in cellular response properties among the ages. Fertilized eggs were obtained from H\&N International (Redmond, WA, USA) and kept in a humidity- and temperature-controlled incubator until hatched when they were transferred to warm brooding cages with a 12:12 h light:dark cycle with food and water ad libitum. Useful data were collected from 36 animals. The University of Washington Animal Care Committee approved animal maintenance procedures and experimental protocols.

Animals were sacrificed by rapid decapitation. The tympanic membrane was removed followed by the columella and the oval window to expose the basilar papilla. Bone and cartilage around the entire cochlea was cleared to allow access. The basilar papilla was pinched with fine forceps at the extreme basal tip and lifted out of its bony casing. Following removal, the basilar papilla was placed in Hanks' buffered saline solution (HBSS), pH 7.4 (Life Technologies, Grand Island, NY, USA). The overlying tegmentum vasculosum was removed and the basilar papilla was transferred to a solution of HBSS and $0.01 \%$ collagenase type I (Sigma). After approximately $3 \mathrm{~min}$, the tectorial membrane could be lifted off of the sensory epithelium and the papilla was transferred back to HBSS and stored at $4^{\circ} \mathrm{C}$ until the recording chamber was prepared, 30 min-1 h later.

Individual basilar papilla were placed in the recording chamber with the apical surfaces of the hair cells facing up. The tissue was held in place by a set of nylon threads secured to a horse-shoe-shaped platinum weight, and viewed through a $40 \times$ immersion objective on an Axioskop (Zeiss, Germany) upright microscope equipped with infra-red illumination and Nomarski optics. The chamber was continuously superfused with oxygenated $\left(95: 5 \quad \mathrm{O}_{2} / \mathrm{CO}_{2}\right)$ artificial perilymph (in mM: $130 \mathrm{NaCl}, 26 \mathrm{NaHCO}_{3}, 1.3 \mathrm{NaH}_{2} \mathrm{PO}_{4}, 3 \mathrm{KCl}$, $2 \mathrm{CaCl}_{2}, 1 \mathrm{MgCl}_{2}, 10$ dextrose) through a gravity feed system with the excess siphoned off by vacuum. In experiments calling for more than one solution, all solutions were kept in separate lines until converging at a Warner Inst. Corp. (Hamden, CT, USA) P6 manifold 
placed about $2 \mathrm{~cm}$ from the recording chamber to allow for quick solution changes. A $\mathrm{Ca}^{2+}$-free solution was used in which the $\mathrm{Ca}^{2+}$ of the standard artificial perilymph external solution was replaced with an equimolar amount of $\mathrm{Mg}^{2+}$. In the text and figures, this solution will be referred to as the low- $\mathrm{Ca}^{2+}$ external solution. TEA solutions were made by adding $0.1,0.5,1,5$ or $10 \mathrm{mM}$ TEA (Sigma) to the standard external solution. 4-AP solutions were made by adding $0.8 \mathrm{mM} 4$-AP to the standard external solution, and the $\mathrm{Cs}^{+}$solution was made by adding $5 \mathrm{mM} \mathrm{CsOH}$ to the standard external and correcting the $\mathrm{pH}$ to 7.2. Experiments were performed at a room temperature of $22.4^{\circ} \mathrm{C}$.

Only cells that had a smooth, luminescent appearance under the microscope were used for recordings. Cells that looked swollen, granular or had begun to bleb were avoided. Only tall hair cells were selected for this study. To be sure that only tall hair cells were used, cells were only recorded from along the superior edge of the papilla. Cells were recorded with the pipet attached to their baso-lateral surface. In many cases this surface was accessible for recording due to the curve of the papilla along the superior edge. The patch electrodes were lowered from above at an angle to reach between the apical surfaces of the hair cells and nestle up against the baso-lateral surface. However, if cells in areas of interest along the tonotopic axis for a particular experiment could not be reached, a glass micropipet pulled as fine as possible was used to create a trough. The micropipet was drawn gently across the apical surface of the basilar papilla such that the tip just barely touched the papilla. The trough would expose a pathway for the recording pipet to the basolateral surface of the hair cells. The positions of all hair cells studied were recorded from the infra-red video image onto a map of the basilar papilla, and expressed as percent distance from apical tip of the sensory epithelium.

\subsection{Recording techniques}

Whole-cell, tight-seal recordings (Hamill et al., 1981) were made on individual tall hair cells using a patchclamp amplifier with a capacitive headstage (Axopatch 200, Axon Instruments, Burlingame, CA, USA). Patch pipets were fabricated from hematocrit tubing (VWR Scientific, San Francisco, CA, USA) and pulled on a vertical puller (David Kopf Instruments, Tujunga, CA, USA). Electrodes were filled with an internal solution containing (in $\mathrm{mM}$ ): $1 \mathrm{MgCl}_{2}, 35 \mathrm{KCl}, 105 \mathrm{Kgluconate}$, 5 EGTA, 10 HEPES and buffered to $\mathrm{pH} 7.2$ with $\mathrm{KOH}$. Open-tip resistance measured in the grounded bath saline ranged between 5 and $6 \mathrm{M} \Omega$ and the junction potential of the internal solution was $-7 \mathrm{mV}$. All membrane potentials indicated have been corrected for junction potential. During each recording, a series resistance was monitored regularly and compensated $85 \%$ using the amplifier's analog controls. Recordings in which series resistance exceeded $14 \mathrm{M} \Omega$ were discarded from the analysis. All recordings were corrected for uncompensated series resistance. Voltage-clamp traces are shown without leak subtraction because of the presence of a variable inward rectifier current in some cells.

Recordings were filtered at $2 \mathrm{kHz}$ (8-pole Bessel) and sampled at $20 \mathrm{kHz}$. Data were digitized at 16-bit resolution (ITC-16, Instrutech Corp., Great Neck, NY, USA) and stored by computer (Power Macintosh 6500/250) for off-line analysis. Synapse 2.2 software (Synergy Research Corp., Bethesda, MD, USA) was used to write stimulus protocols and record hair cell responses. Data were analyzed using either Cricket Graph III (Cricket Software, Malvern, PA, USA) or Microsoft Excel 5 (Microsoft Corp., Redmond, WA, USA) and figures were constructed using either Igor Pro 3.03 (WaveMetrics, Lake Oswego, OR, USA) or Canvas 3.5 (Deneba Software, Miami, FL, USA). A total of 45 cells yielded recordings with low series resistance and very small leak currents, as determined by current versus voltage $(I / V)$ analysis, and were subsequently used in this study.

\section{Results}

Using the intact basilar papilla preparation, we investigated the physiology of chick auditory hair cells. This preparation allowed the results of the recordings to be mapped in detail along the epithelium. Whole-cell recordings using this preparation showed that there was a continuous tonotopic increase in the total amount of the cells' outward currents from apex to about $60 \%$ towards the base where cells have a characteristic frequency of about $2 \mathrm{kHz}$ (Chen et al., 1994). Hair cells located more than $60 \%$ towards the base were not recorded from in the study because their health was questionable due to either a granular appearance or to blebbing. The main outward current of tall hair cells consisted of two distinct types of potassium currents, a voltage-activated $\mathrm{K}^{+}$current, $I_{\mathrm{K}}$, and a calcium-activated $\mathrm{K}^{+}$current, $I_{\mathrm{K}(\mathrm{Ca})}$ (Fuchs and Evans, 1990). In this study, all tall hair cells recorded displayed both outward $\mathrm{K}^{+}$currents. Apical tall hair cells also showed an inward rectifier $\mathrm{K}^{+}$current $\left(I_{\mathrm{IR}}\right)$. In addition, both outward $\mathrm{K}^{+}$currents showed an increase in magnitude from apex to base. The combination of these two $\mathrm{K}^{+}$ currents created the tonotopic gradient in amplitude of outward current seen in this study.

Fig. 1 shows the increase in total outward current from apex to base of the chick basilar papilla. For all 

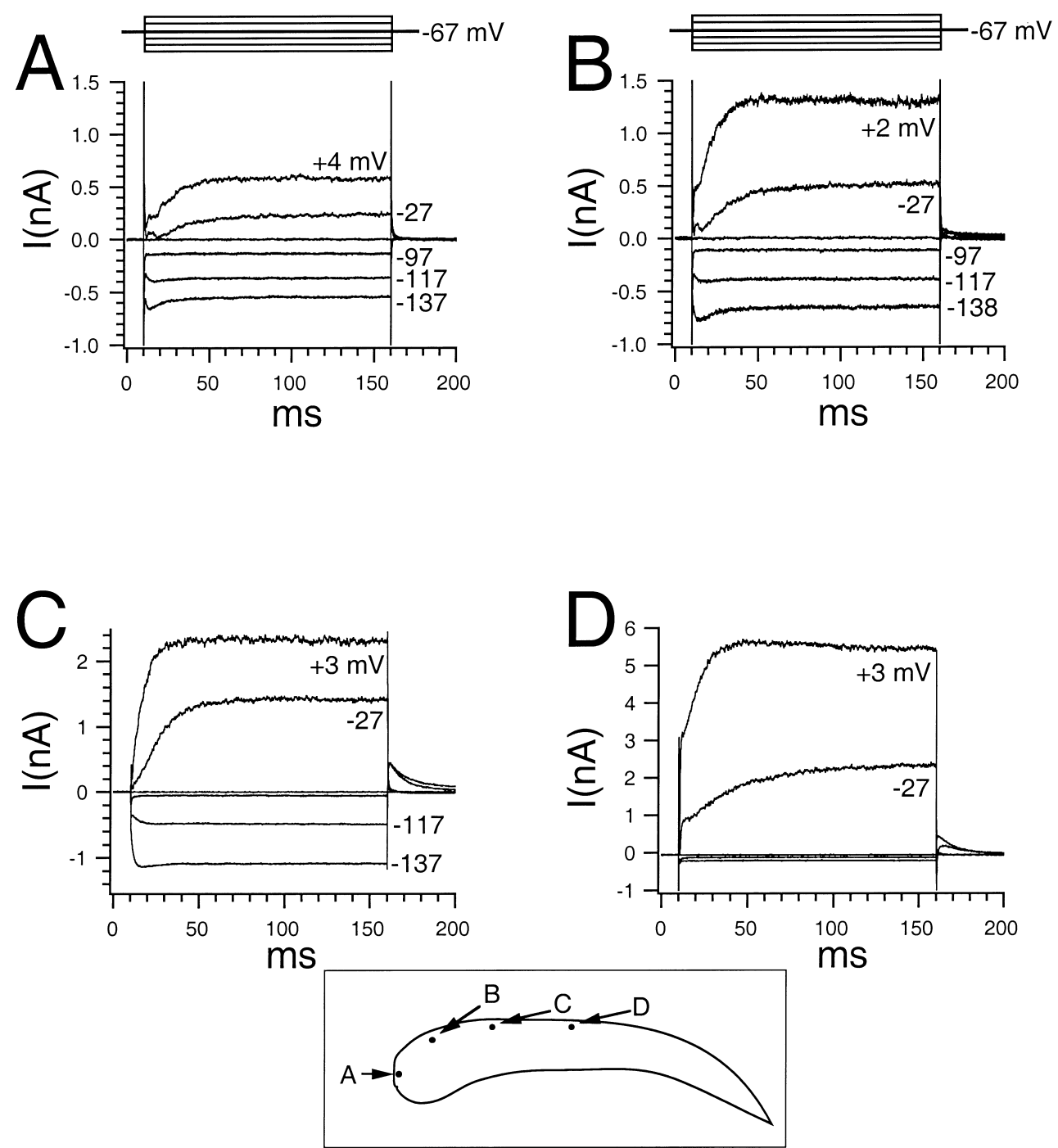

Fig. 1. Voltage-clamp recordings of tall hair cells along the basilar papilla shown with a schematic of the papilla depicting each cell's location. A: Voltage clamp of a cell at the apical-most tip. B: Cell $9 \%$ from apex. C: Cell $22 \%$ from apex. D: Cell $40 \%$ from apex. All cells were clamped to a holding potential of $-67 \mathrm{mV}$ and voltage steps (corrected for residual series resistance here and in all subsequent figures) were $150 \mathrm{~ms}$ in duration. Notice the change in scales in $\mathrm{C}$ and $\mathrm{D}$. Inset at the bottom shows the schematic of the basilar papilla (apex to left) with position of hair cells recorded for this and all subsequent figures indicated by dots.

voltage-clamp traces shown, the holding membrane potential $\left(V_{\mathrm{H}}\right)$ was $-67 \mathrm{mV}$ and step commands are 150 $\mathrm{ms}$ in duration presented in $10 \mathrm{mV}$ increments. The cells in Fig. 1 were located at the apical tip (A), 9\% (B), 22\% (C) and 40\% (D) from the apex. There was a continuous increase in outward current recorded in voltageclamp mode as distance from the apex increases. Notice the change in scale in $\mathrm{C}$ and again in $\mathrm{D}$. During hyperpolarizing steps to $-117 \mathrm{mV}$, an inward rectifier current $\left(I_{\mathrm{IR}}\right)$ was activated in the more apical cells $(\mathrm{A}, \mathrm{B}$ and $\mathrm{C})$ and was not present in the most basal cell (D). The position of each cell is shown in the schematic of a surface view of the papilla. In this and subsequent figures, the basal end is towards the right.

$I / V$ graphs for three representative cells along the tonotopic axis of the basilar papilla are shown in Fig. 2. This figure compares the magnitude of the outward currents for a cell located at the apical tip (Fig. 2A), a cell located 15\% from apex to base (Fig. 2B) and a cell located $45 \%$ from apex to base (Fig. 2C). Note the differences in scales for the currents in each of the $I / V$ curves. The graphs in Fig. 2 were generated by measuring steady-state current at the end of $150 \mathrm{~ms}$ voltage steps delivered at $10 \mathrm{mV}$ increments from $V_{\mathrm{H}}=-77$ for Fig. 2A and $V_{\mathrm{H}}=-67$ for Fig. 2B,C. These plots show that the outward current activated in all three cells between -55 and $-45 \mathrm{mV}$. The $I / V$ plots also show that $I_{\mathrm{IR}}$ was absent in hyperpolarizing steps in the most basal cell. In the majority of basal cells, $I_{\mathrm{IR}}$ was not seen. 

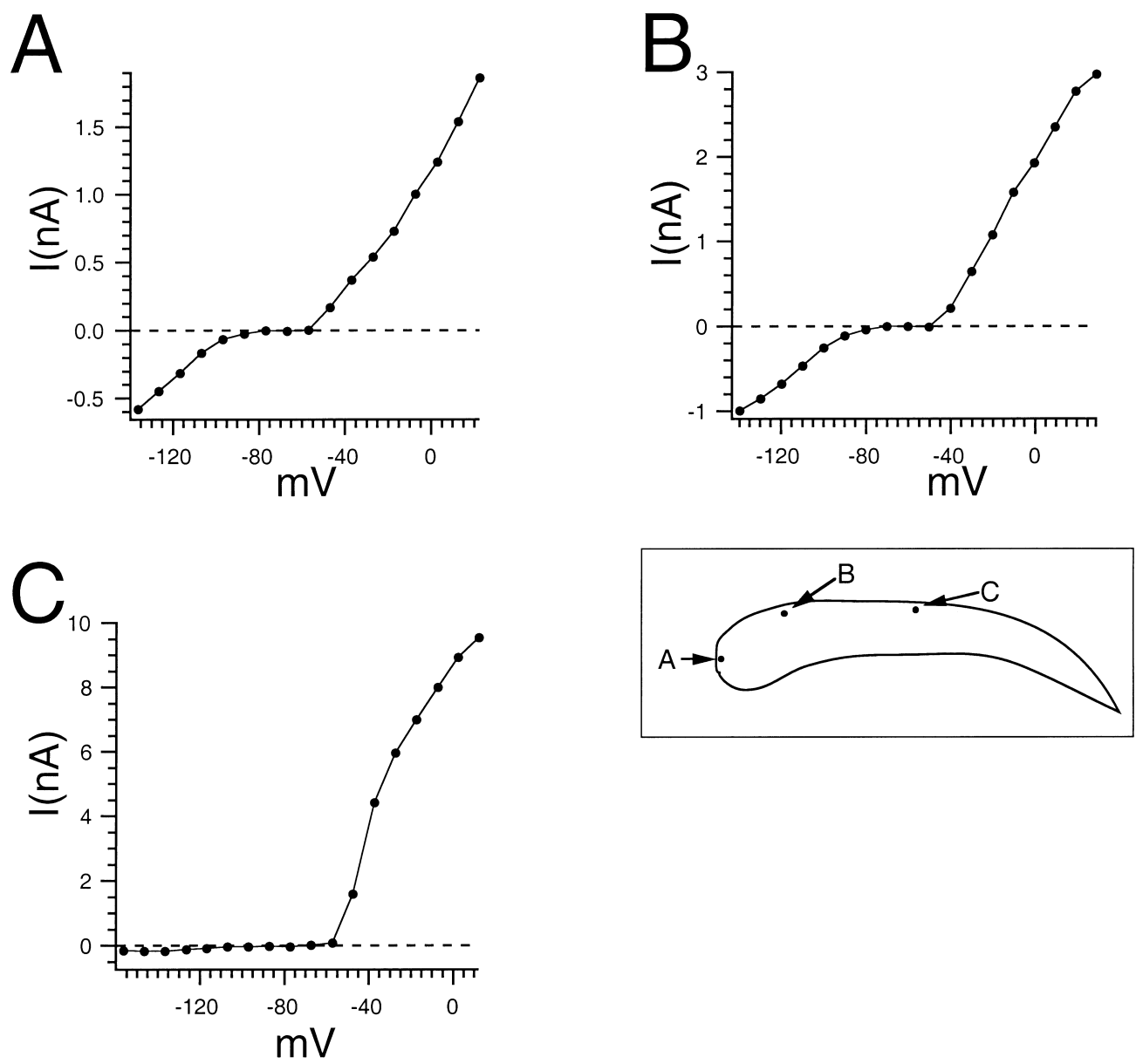

Fig. 2. $I / V$ curves for three tall hair cells at various positions along the basilar papilla. There is an increase in total outward current from a cell at the apical tip (A), 15\% from the apex (B) and 45\% from the apex (C). Notice the change in scales for each curve. The inward rectifier $\left(I_{\mathrm{IR}}\right)$ was present in the two more apical cells $(\mathrm{A}$ and $\mathrm{B})$ and not present in the more basal cell $(\mathrm{C})$. The $I / V$ curves were made by measuring the current $140 \mathrm{~ms}$ into $150 \mathrm{~ms}$ voltage steps given in $10 \mathrm{mV}$ increments from $V_{\mathrm{H}}=-77$ (A) or -67 (B and C).

\subsection{Outward currents}

Two distinct outward currents were resolved based on their kinetics and pharmacology. Recordings shown in Fig. 3 exemplify this. These recordings were from a cell located $1 \%$ from the apex. Two components of outward current with different activation time constants $(\tau)$ can be seen in Fig. 3A,B. The traces are from the same voltage-clamp series of the same cell presented on different time scales. The two current components were separately fitted to single exponentials in order to calculate the $\tau$. The initial outward component was quite fast, which is shown in Fig. 3A where voltage steps from $V_{\mathrm{H}}=-67 \mathrm{mV}$ to the voltages indicated beside each trace yield $\tau$ s of $0.69,0.47$ and $0.40 \mathrm{~ms}$. The second component was much slower, as shown in Fig. 3B, where single exponential fits give $\tau$ of $27.70,11.74$ and $11.22 \mathrm{~ms}$. Fig. 3C shows recordings from the same cell when bathed in $10 \mathrm{mM}$ TEA. The fast component was reduced, allowing the remaining current to be fitted more cleanly to a single exponential curve from onset.
Voltage steps similar to those in Fig. 3B were applied giving $\tau$ of $29.91,13.55$ and $11.24 \mathrm{~ms}$, which are very similar to the $\tau$ calculated for the slow component in the absence of TEA (as shown in Fig. 3B).

\section{2. $\mathrm{Ca}^{2+}$ and TEA sensitivity of the outward currents}

The calcium dependence of the outward currents was tested by bathing the basilar papilla in a solution where an equimolar amount of $\mathrm{Mg}^{2+}$ replaced $\mathrm{Ca}^{2+}(n=16)$. Generally, the low- $\mathrm{Ca}^{2+}$ external solution did not affect the resting membrane potential or it caused a slight hyperpolarization of less than $5 \mathrm{mV}$. The sensitivity of the outward currents to TEA was tested by bathing the basilar papilla in solutions with various molarities of TEA ranging from $0.1 \mathrm{mM}$ to $10 \mathrm{mM}(n=6)$. The addition of TEA to the bath did not affect the resting membrane potentials of the cells. The separation of the outward currents using these pharmacological manipulations is demonstrated in Fig. 4. Fig. 4 shows that both of these manipulations substantially reduced the 

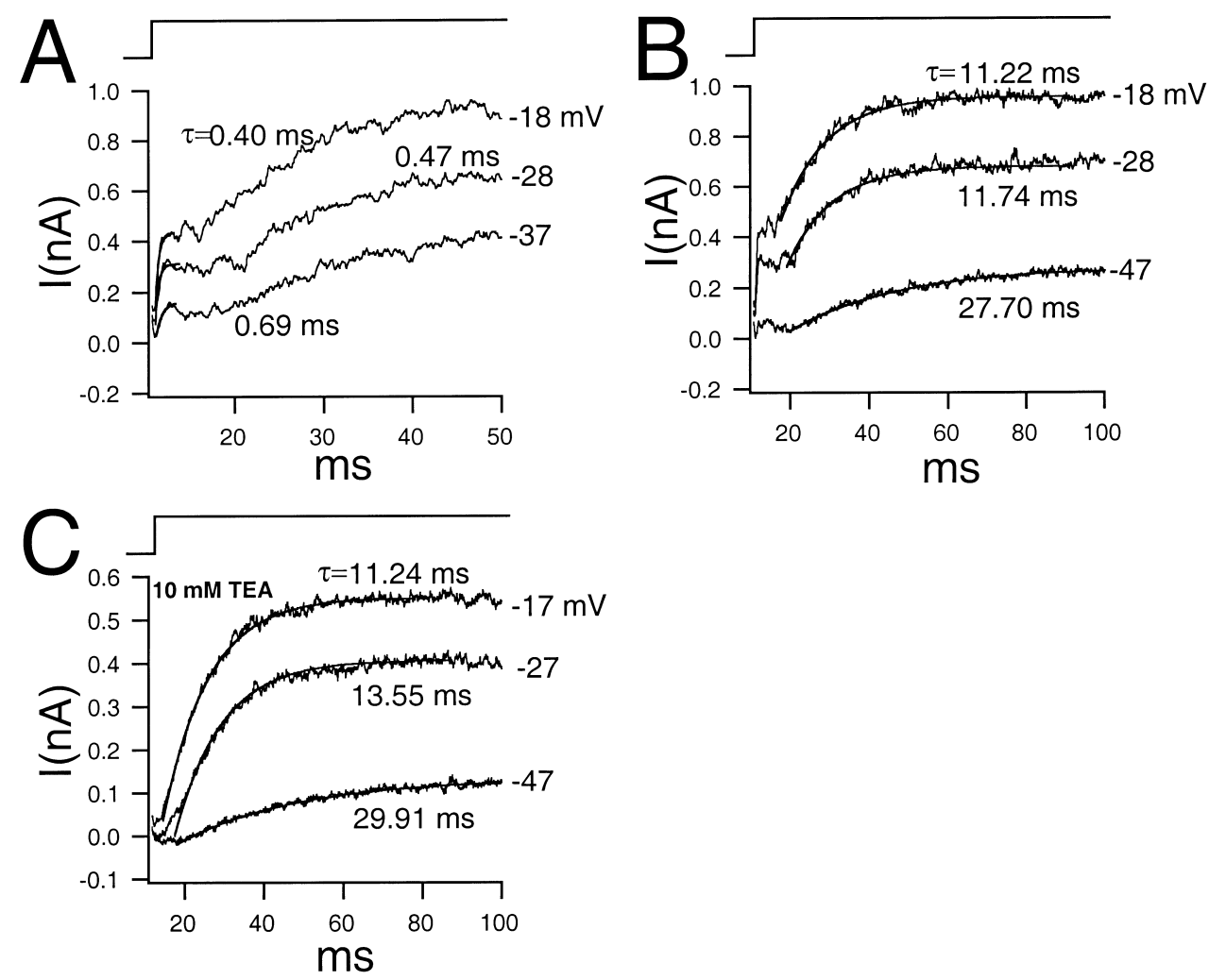

Fig. 3. Comparison of the kinetics of the fast and slow current components in a single tall hair cell located 1\% from the apex. A: The fast current component elicited by $150 \mathrm{~ms}$ voltage steps from a $V_{\mathrm{H}}$ of $-67 \mathrm{mV}$ to the voltages indicated next to each trace is shown on an expanded time scale. The current is activated immediately after the onset of the steps. When fitted to single exponential curves $\tau \mathrm{s}$ of $0.69,0.47$ and 0.40 $\mathrm{ms}$, respectively, are found. B: The slow component of the same cell shown in A on a longer time scale and fitted to single exponential curves with $\tau$ of $27.70,11.74$ and $11.22 \mathrm{~ms}$. The fit was started at the point where the fast component levelled off and the slow component began to rise. C: The fast component was then blocked by the addition of $10 \mathrm{mM}$ TEA to the external solution leaving just the slow component and the $\tau$ were re-calculated to be $29.91,13.55$ and $11.24 \mathrm{~ms}$ for similar voltage steps.

faster outward current component while the slower current remains. Based on previous work (Fuchs and Evans, 1990; Art et al., 1993), it is likely that the TEA sensitive current is $I_{\mathrm{K}(\mathrm{Ca})}$ while the remaining current, that is not blocked by TEA and has slower kinetics, is $I_{\mathrm{K}}$. The left panel of Fig. 4A shows voltageclamp recordings from a cell located near the apical tip of the basilar papilla. When this cell was bathed in 10 $\mathrm{mM}$ TEA, the initial fast outward $I_{\mathrm{K}(\mathrm{Ca})}$ was eliminated leaving most of the slow voltage-activated $I_{\mathrm{K}}$. Eliminating $I_{\mathrm{K}(\mathrm{Ca})}$ in this cell revealed a rapidly activating inward current likely to be $I_{\mathrm{Ca}}$. To test whether this inward current was, in fact, $I_{\mathrm{Ca}}$, the cell was superfused with a low- $\mathrm{Ca}^{2+}+10 \mathrm{mM}$ TEA solution. As shown in the trace marked 'low $\mathrm{Ca}^{2+}+\mathrm{TEA}$ ', this procedure eliminated the rapidly activated inward current, again suggesting that the current was $I_{\mathrm{Ca}}$. The right panel of Fig. 4A shows that the inward current returned in a first wash-out when $\mathrm{Ca}^{2+}$ was added back to the $10 \mathrm{mM}$ TEA solution, and $I_{\mathrm{K}(\mathrm{Ca})}$ returned in a second washout when the $10 \mathrm{mM}$ TEA solution was replaced with control superfusate.
The effect of low external $\mathrm{Ca}^{2+}$ on a cell located more basally is shown in Fig. 4B. This cell is located 58\% from the apex. When the hair cell was bathed in low$\mathrm{Ca}^{2+}$ solution, the amount of total outward current decreased. As with the apical cell, the low- $\mathrm{Ca}^{2+}$ sensitive current is likely to be $I_{\mathrm{K}(\mathrm{Ca})}$ while the residual, slower outward current is $I_{\mathrm{K}}$. Previous studies on chick tall hair cells have shown that reducing the external $\mathrm{Ca}^{2+}$ in basal cells abolished almost all the outward current (Fuchs and Evans, 1990). In the present study, however, although $I_{\mathrm{K}(\mathrm{Ca})}$ is quite large, there is still a significant amount of outward current, $I_{\mathrm{K}}$, activated in the low- $\mathrm{Ca}^{2+}$ solution.

Fig. 4C shows the sensitivity of the outward currents to TEA of the same basal cell as pictured in Fig. 4B. Voltage-clamp recordings were made in control superfusate and with the addition of $10 \mathrm{mM}$ TEA. Similar to results obtained by bathing basal cells in a low-Ca ${ }^{2+}$ solution, the addition of TEA to the external solution reduced the outward current significantly by blocking $I_{\mathrm{K}(\mathrm{Ca})}$. Again, notice that there was still a substantial amount of the slower activating $I_{\mathrm{K}}$ left after $I_{\mathrm{K}(\mathrm{Ca})}$ 

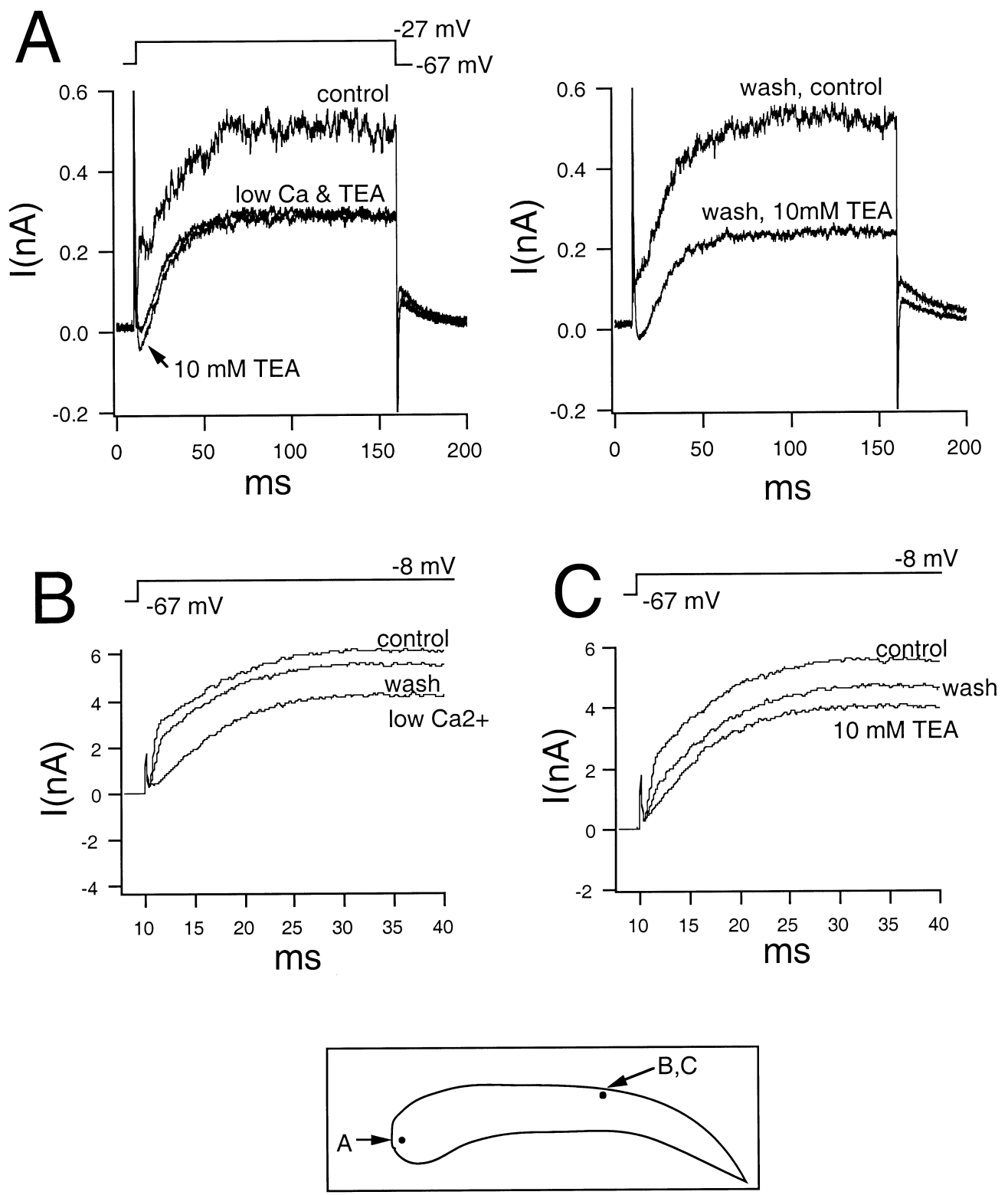

Fig. 4. Effect of low-Ca ${ }^{2+}$ external solution and TEA on the outward currents of tall hair cells. The locations of the cells are depicted on the schematic. A: This cell is located $2 \%$ from the apex. In voltage clamp, $10 \mathrm{mM}$ TEA (trace marked ' $10 \mathrm{mM}$ TEA') reduced the fast component of the outward current and revealed an inward current that is blocked by superfusing the cell in a $10 \mathrm{mM}$ TEA, low-Ca ${ }^{2+}$ external solution (trace marked 'low $\mathrm{Ca}^{2+}$ and TEA'). The right panel shows that the inward current returned when the cell was bathed again in just $10 \mathrm{mM}$ TEA. The fast component recovered during the wash with control superfusate. Holding potential for all recordings was $-67 \mathrm{mV}$ and all voltage steps were $150 \mathrm{~ms}$ in duration. B: Effect of low- $\mathrm{Ca}^{2+}$ external solution on a hair cell, $58 \%$ from the apex. Replacing external $\mathrm{Ca}^{2+}$ with $\mathrm{Mg}^{2+}$ reduced the magnitude of the outward current, which almost fully recovered in the wash. C: Effect of TEA in the external solution on the same cell located 58\% from the apex. The addition of TEA reduced the outward current most notable at onset. The current partially recovered in wash. In all voltage-clamp traces for this cell, the cell was held at $-67 \mathrm{mV}$ and stepped for $150 \mathrm{~ms}$ to $-8 \mathrm{mV}$.

is blocked. The current began to recover in the washout.

\subsection{4-AP sensitivity of the outward currents}

In order to separate the two outward currents further, $0.8 \mathrm{mM}$ 4-AP was added to the external solution $(n=16)$. Previous work has shown that this concentra- tion of 4-AP effectively blocks the voltage-activated $I_{\mathrm{K}}$ in turtle hair cells while not significantly affecting $I_{\mathrm{K}(\mathrm{Ca})}$ (Goodman and Art, 1996b). Fig. 5A shows the effect of 4-AP on the outward current of a representative apical tall hair cell. The cell was held at $-67 \mathrm{mV}$ and was given $150 \mathrm{~ms}$ voltage steps. In the presence of 0.8 $\mathrm{mM} 4$-AP in the external solution, the outward current was substantially reduced. In addition, the activation 

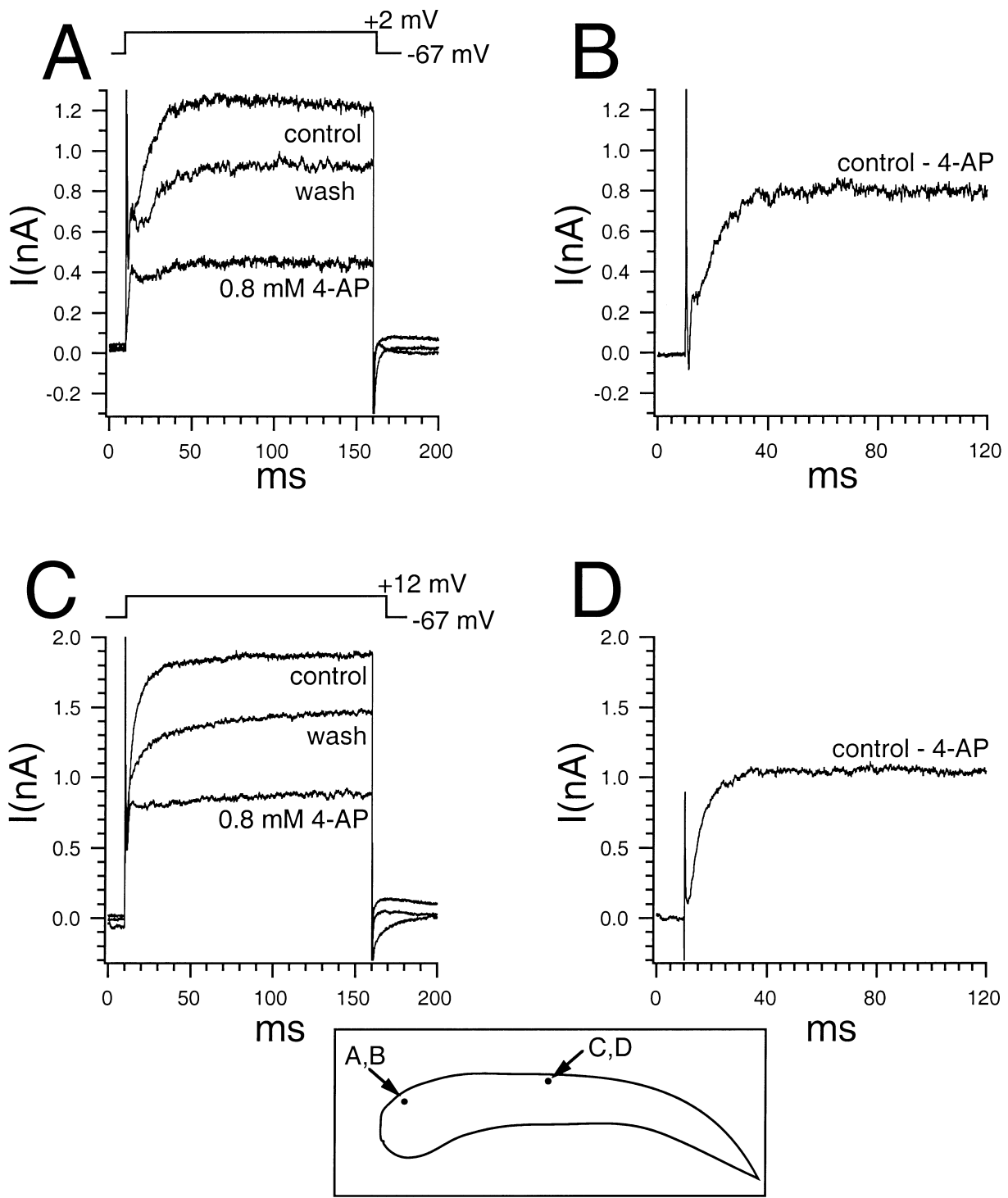

Fig. 5. Effect of 4-AP on the current responses of tall hair cells. A: Voltage-clamp recording demonstrating that outward current was greatly reduced with the presence of $0.8 \mathrm{mM} \mathrm{4-AP}$ in the external solution. The current partially recovered in the wash. For all three traces, the cell was held at $-67 \mathrm{mV}$ and stepped for $150 \mathrm{~ms}$ to $+2 \mathrm{mV}$. B: The subtraction current of this apical cell at $+2 \mathrm{mV}$ (control current minus current in 4-AP) shown on an expanded time scale. This represents the current blocked by 4-AP. C: The effect of 4-AP on the outward current of a hair basal cell located $41 \%$ from the apex. Voltage-clamp recordings of this cell show that there was a substantial amount of outward current that was blockable by $0.8 \mathrm{mM}$ 4-AP. The blocked current partially recovered in the wash. All three traces show $150 \mathrm{~ms}$ voltage steps from $V_{\mathrm{H}}=-67$ to $+12 \mathrm{mV}$. D: The subtraction current at $+12 \mathrm{mV}$ of the control trace and the 4-AP trace shown on an expanded time scale.

kinetics of the residual outward current became much faster. Based on the known pharmacological and kinetic differences between the two outward $\mathrm{K}^{+}$currents, treatment with $0.8 \mathrm{mM}$ 4-AP had blocked $I_{\mathrm{K}}$ leaving the faster, 4-AP insensitive $I_{\mathrm{K}(\mathrm{Ca})}$. $I_{\mathrm{K}}$ only partly recovered after a long wash of $20 \mathrm{~min}$ or more. Fig. 5B shows the subtraction current calculated from the voltage-clamp trace in control external solution and the voltage-clamp trace in $0.8 \mathrm{mM} \mathrm{4-AP}$ for steps to +2 $\mathrm{mV}$. This trace represents an approximation of $I_{\mathrm{K}}$. Notice that the subtraction current activates more slowly than the residual $I_{\mathrm{K}(\mathrm{Ca})}$. The subtraction current also shows a small amount of fast outward current, which suggests that some $I_{\mathrm{K}(\mathrm{Ca})}$ may also have been blocked by 4 -AP.

As shown in Fig. 4, the residual current present in basal hair cells when bathed either in low- $\mathrm{Ca}^{2+}$ or TEA solution was also proposed to be $I_{\mathrm{K}}$, based on its slower speed and its pharmacology. To test this assumption, $0.8 \mathrm{mM} 4$-AP was added to the external solution while recording from a more basal cell. If $I_{\mathrm{K}}$ was still present in basal cells then a significant amount of the total outward current should be blockable by 4-AP. Fig. 5C shows the results of this experiment in a cell located 
$41.3 \%$ from the apex. The cell was held at $-67 \mathrm{mV}$ and stepped to $+12 \mathrm{mV}$ for $150 \mathrm{~ms}$. The addition of $0.8 \mathrm{mM}$ 4-AP to the external solution did reduce the amount of outward current by eliminating the slower current component. As a result, the remaining outward current was the faster current component. The 4-AP sensitive current is expressed in Fig. 5D as the subtraction current of the control voltage-clamp trace and the voltageclamp trace in 4-AP for steps to $+12 \mathrm{mV}$. As in the apical cell, the subtraction current had slower activation kinetics than the unblocked current. The subtraction current is, again, an approximation of the blocked $I_{\mathrm{K}}$. Therefore, both apical and more basal cells have significant amounts of both $I_{\mathrm{K}}$ and $I_{\mathrm{K}(\mathrm{Ca})}$, which are at least partially separable using these pharmacological manipulations.

\subsection{Effect of external $\mathrm{Cs}^{+}$on $I_{I R}$}

Low-frequency apical hair cells, in addition to the two outward potassium currents, also have an inward rectifier potassium current, $I_{\mathrm{IR}}$, that is activated at hyperpolarized potentials. Our observations and previous studies of isolated chick hair cells (Fuchs and Evans, 1990) indicate that more basal, high-frequency hair cells do not have this current. Likewise, turtle hair cells tuned to the lower frequencies have $I_{\mathrm{IR}}$, and as resonance frequency increases, $I_{\mathrm{IR}}$ decreases. Blocking $I_{\mathrm{IR}}$ in turtle hair cells resulted in a distinct decrease in the quality of resonance (Goodman and Art, 1996a). In addition, it has been shown in both turtle hair cells of the lower frequencies (Goodman and Art, 1996a) and chick isolated apical hair cells (Fuchs and Evans, 1990) that $5 \mathrm{mM} \mathrm{Cs}^{+}$in the external solution can block $I_{\mathrm{IR}}$. Therefore, this concentration of $\mathrm{Cs}^{+}$was used in our experiments to block this current $(n=6)$.

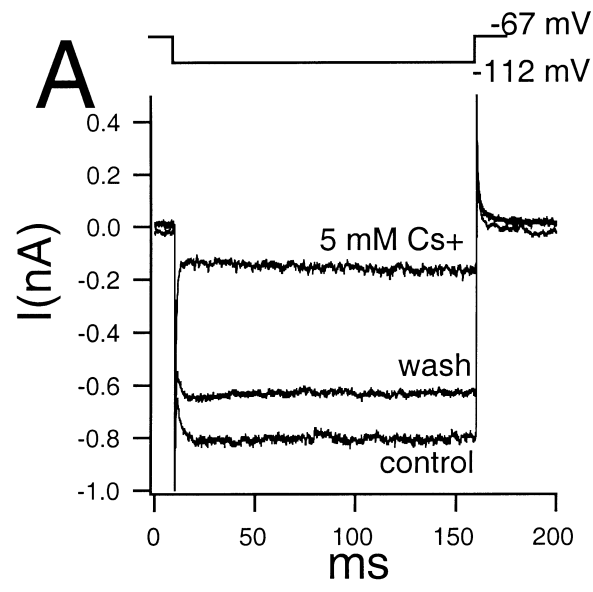

Fig. 6 shows the effect of $5 \mathrm{mM} \mathrm{Cs}^{+}$in the external solution on $I_{\mathrm{IR}}$ in a cell at the apical tip. Fig. $6 \mathrm{~A}$, in the trace marked 'control', shows that $I_{\mathrm{IR}}$ was activated by a $150 \mathrm{~ms}$ voltage step from $V_{\mathrm{H}}=-67$ to $-112 \mathrm{mV}$. The same voltage step with the addition of $\mathrm{Cs}^{+}$to the external solution shows that $I_{\mathrm{IR}}$ was blocked, as can be seen in the trace marked, ' $5 \mathrm{mM} \mathrm{Cs}^{+}$. The current returned to near normal as the $\mathrm{Cs}^{+}$was washed out. The effect of blocking $I_{\mathrm{IR}}$ on the voltage/current relationship of the steady-state outward current of an apical tall hair cell is shown in Fig. 6B. Steady-state current was measured at the end of $150 \mathrm{~ms}$ voltage steps given in $10 \mathrm{mV}$ increments from $V_{\mathrm{H}}=-67$. In $\mathrm{Cs}^{+}$, the response to hyperpolarizing steps flattens reflecting the block of $I_{\mathrm{IR}}$. For all apical cells recorded in $\mathrm{Cs}^{+}$containing external solution $(n=6)$, there was no significant effect on the outward currents measured at more depolarized voltage steps.

\subsection{Mapping of the papilla}

Since the entire intact basilar papilla was explanted in each of our preparations, we could determine the relationships between various electrophysiological characteristics and the positions of the hair cells along the length (tonotopic axis) of the papilla. Fig. 7 presents these data for steady-state current (Fig. 7A), current in low external $\mathrm{Ca}^{2+}$ (Fig. 7B) and the subtraction current in low external $\mathrm{Ca}^{2+}$, which approximates $I_{\mathrm{K}(\mathrm{Ca})}$ (Fig. 7C). In Fig. 7, the position of each cell along the papilla is indicated on the abscissa and the parameter value is indicated on the ordinate. In Fig. 7A, the solid line describes the best fit exponential regression with the $r^{2}$ value indicated at the bottom right. Sample size $(n)$ is indicated in all three graphs at the bottom right. For the three graphs shown in Fig. 7, holding

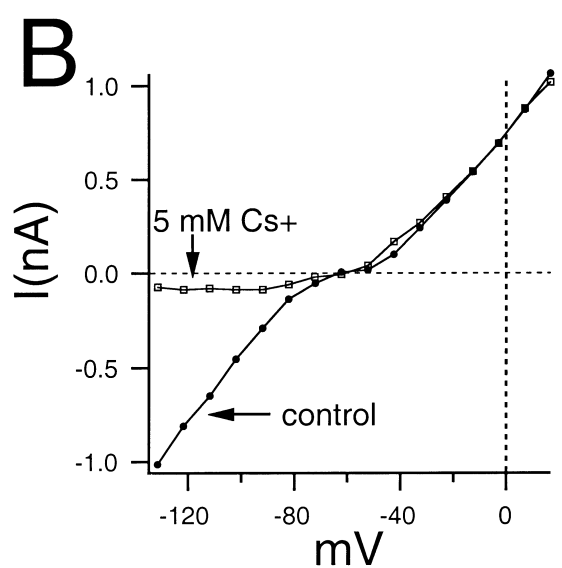

Fig. 6. Effect of external $\mathrm{Cs}^{+}$on $I_{\mathrm{IR}}$ of apical hair cells. A: Voltage-clamp recording of a hair cell located near the apex of the papilla showing the affect of $5 \mathrm{mM} \mathrm{Cs}^{+}$in the external solution on $I_{\mathrm{IR}}$. A $150 \mathrm{~ms}$ voltage step from $V_{\mathrm{H}}=-67 \mathrm{mV}$ to $-112 \mathrm{mV}$ demonstrates that $I_{\mathrm{IR}}$ is activated in control external solution, reduced in the presence of $5 \mathrm{mM} \mathrm{Cs}^{+}$and partially recovers in the wash. B: Plot of current versus membrane voltage for control (closed circles) and $5 \mathrm{mM} \mathrm{Cs}^{+}$(open squares) external solution. 


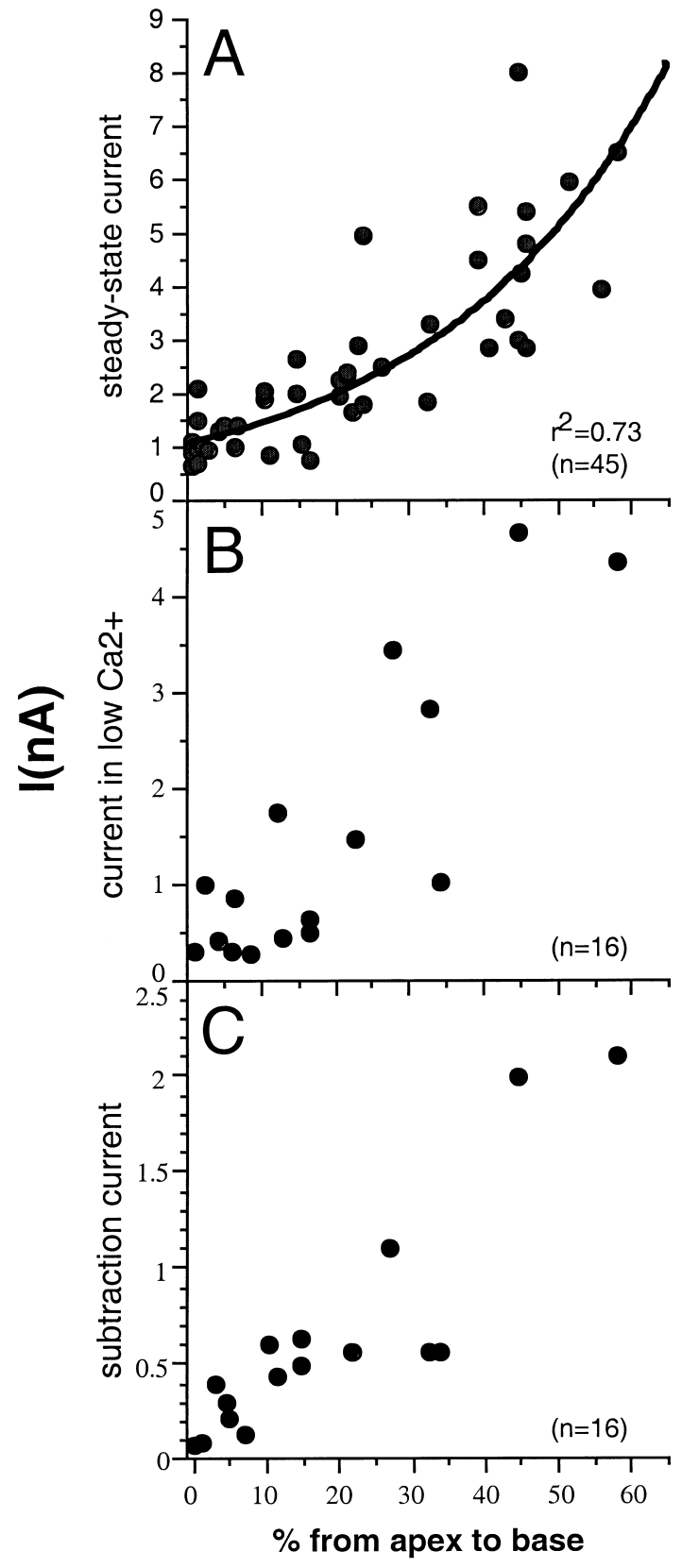

Fig. 7. Maps of total outward steady-state current (A), outward current in low $\mathrm{Ca}^{2+}(\mathrm{B})$, and the subtraction current from voltageclamp traces in control external and in low- $\mathrm{Ca}^{2+}$ external solution (C), plotted against location on papilla expressed as a percentage from apex to base with $0 \%$ denoting the apical tip. Holding potentials were near resting membrane potentials for all cells (between -67 and $-77 \mathrm{mV}$ ). Sample sizes indicated in each graph by $n$. A: Total outward steady-state current was measured at the end of voltage steps. Current at $-7 \mathrm{mV}$ was interpolated from values for voltage steps above and below $-7 \mathrm{mV}$. The data were fitted to an exponential with an $r^{2}$ value of 0.73 . B: Steady-state outward current in low- $\mathrm{Ca}^{2+}$ external solution was used to estimate $I_{\mathrm{K}}$, since $I_{\mathrm{K}(\mathrm{Ca})}$ was largely blocked. Current at $-7 \mathrm{mV}$ was calculated as was described in A. C: The subtraction current was calculated to estimate the magnitude of $I_{\mathrm{K}(\mathrm{Ca})}$. potentials for the cells were near their resting membrane potential of near $-67 \mathrm{mV}$. Cells with series resistances of $14 \mathrm{M} \Omega$ or more were eliminated as well as cells that showed a significant $(>0.2 \mathrm{nA})$ Ohmic conductance at potentials around the holding potential determined during $I / V$ analysis. In this way, cells used for these graphs had little leak current. The locations of the cells were measured as a percentage of total papilla length with $0 \%$ denoting the apical tip. It is apparent in Fig. 7 that we were unable to achieve adequate recordings from hair cells in the basal one-third of the papilla. This problem also plagued previous studies (e.g. Fuchs and Sokolowski, 1990). In our preparations, the basal hair cells would become unhealthy and bleb. It is unknown why these hair cells do not remain healthy in vitro.

Fig. 7A shows the relationship between total, steadystate outward current and location on papilla. Total steady-state current for all cells plotted in Fig. 7A was measured at the end of a $150 \mathrm{~ms}$ voltage step. All voltages were corrected for residual series resistance resulting in a variability in command potentials. Therefore, for each cell, the amount of current at $-7 \mathrm{mV}$ was interpolated from the amount of current recorded at voltage steps to potentials less than and greater than $-7 \mathrm{mV}$. When the results were mapped against place on papilla, it is best fit by an exponential rise in total current amplitude as a function of position from apex to base $\left(r^{2}=0.73\right)$.

This current measurement, therefore, is the sum of both outward $\mathrm{K}^{+}$currents, $I_{\mathrm{K}(\mathrm{Ca})}$ and $I_{\mathrm{K}}$. The measurement of the outward current also will be influenced by the inward $\mathrm{Ca}^{2+}$ current, which will lead to an underestimation of the outward current all along this map. However, these measurements cannot be done in the absence of the $\mathrm{Ca}^{2+}$ current since one of the currents of interest, $I_{\mathrm{K}(\mathrm{Ca})}$, is $\mathrm{Ca}^{2+}$ dependent. Despite the presence of $I_{\mathrm{Ca}}$ which increases in amplitude from apex to base (Martinez-Dunst et al., 1997), the opposing outward current clearly shows a dramatic increase from apex to base, demonstrating that the trend in the magnitude of outward current is still observable. Furthermore, $I_{\mathrm{Ca}}$ was measured with $\mathrm{Ba}^{2+}$ as the current carrier and it was found that this current increases only over a range of about $100 \mathrm{pA}$ over $1.7 \mathrm{~mm}$ of basilar papilla length (Martinez-Dunst et al., 1997). Another possible concern, for apical cells in particular, is $I_{\mathrm{IR}}$. However, as can be seen in Fig. 6B, the presence of $I_{\mathrm{IR}}$ does not affect the measurement of total outward steady-state current at the depolarized membrane potentials used here.

Fig. 7B shows the relationship between the voltageactivated $I_{\mathrm{K}}$ and place on the papilla. $I_{\mathrm{K}}$ was measured at steady-state, at the end of a $150 \mathrm{~ms}$ voltage step under low-Ca ${ }^{2+}$ conditions. Therefore, the majority of current measured would be $I_{\mathrm{K}}$. Current at $-7 \mathrm{mV}$ is 


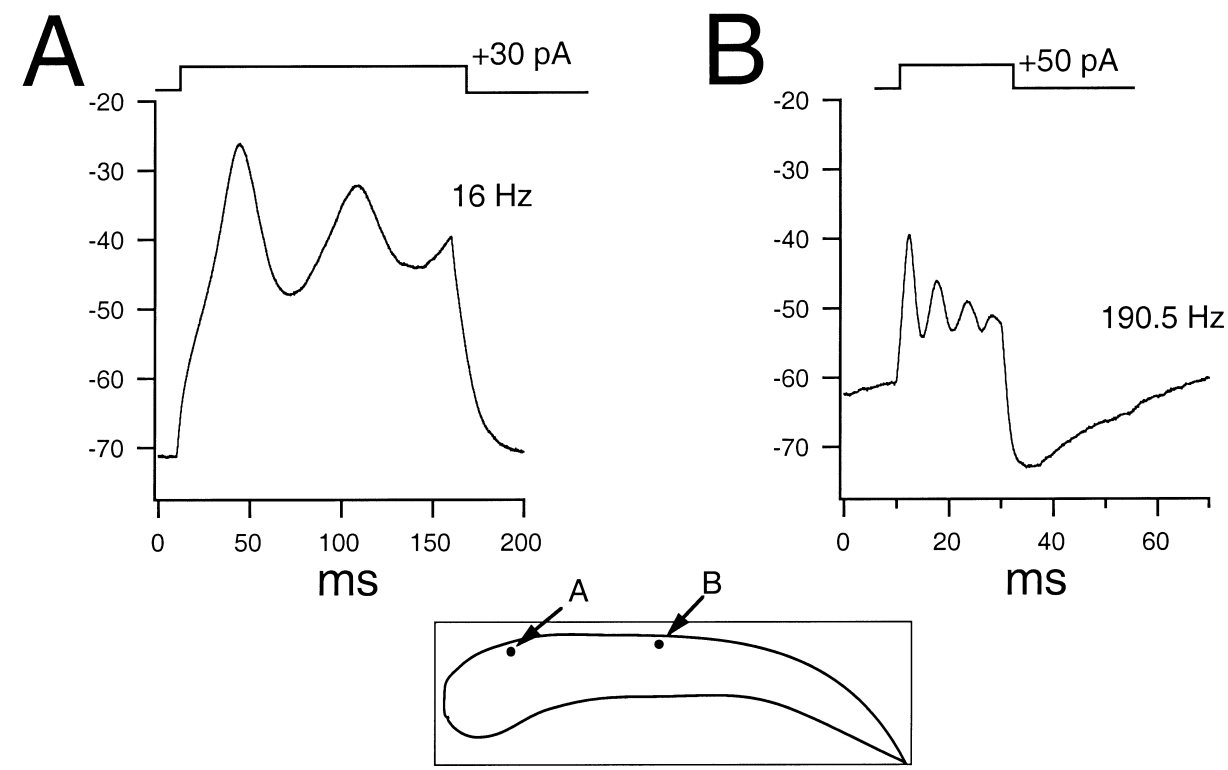

Fig. 8. Current-clamp recordings of two tall hair cells from different areas of the basilar papilla. A: A cell $14.8 \%$ from the apex was depolarized with a $150 \mathrm{~ms},+30 \mathrm{pA}$ step of injected current. Oscillation frequency was $16 \mathrm{~Hz}$. B: A cell $45 \%$ from the apex was depolarized with a $20 \mathrm{~ms},+50 \mathrm{pA}$ current step to reveal oscillations of $190.5 \mathrm{~Hz}$.

plotted and was measured as described for Fig. 7A. When these results are plotted against place on papilla, an increase in current magnitude is seen from apex to base.

Fig. 7C shows the relationship between the subtraction current and place on the basilar papilla. The magnitude of this current was measured by subtracting the amount of outward current activated at $-7 \mathrm{mV}$ in control external and the amount of outward current activated at $-7 \mathrm{mV}$ in low- $\mathrm{Ca}^{2+}$ external solution. This subtraction approximates the magnitude of $I_{\mathrm{K}(\mathrm{Ca})}$, which is present in control external but is not present in low external $\mathrm{Ca}^{2+}$. When these values are plotted against place on papilla, an increase in magnitude is seen from apex to base. For all three graphs, note the changes in scales.

\subsection{Current-clamp recording of membrane voltage oscillations}

We recorded from 20 cells in current-clamp mode in which we observed the membrane voltage responses of cells during steps of depolarizing current injections. All cells displayed a damped, sinusoidal membrane voltage oscillation similar to responses reported by Fuchs and Evans (1990). However, the frequency of these oscillations was either on the order of $12-23 \mathrm{~Hz}$ or above 120 Hz. Cells located in the apical $35 \%$ of the basilar papilla showed the slower oscillations while cells more basal abruptly began to display the faster oscillations. No cells were recorded from that oscillated between 25 and $120 \mathrm{~Hz}$ despite that fact there was a smooth gra- dient in the locations of the cells along the tonotopic axis. Fig. 8 shows typical examples of these oscillations for both frequency groups. Fig. 8A shows a cell located $14.8 \%$ from the apex which, when depolarized with +30 pA current injection, oscillated at $16 \mathrm{~Hz}$. Fig. 8B, however, shows a more basal cell, located $45 \%$ from the

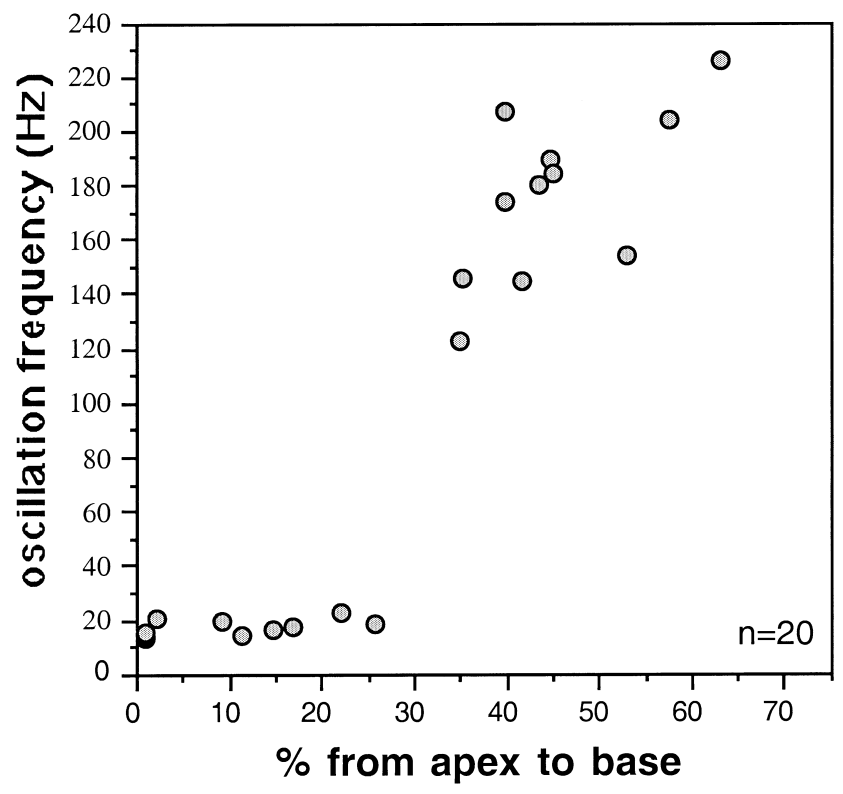

Fig. 9. Map of oscillation frequency versus location on papilla expressed as a percentage from apex to base with $0 \%$ denoting the apical tip. Oscillation frequency was measured at the best resolved frequency. Notice the sharp increase in frequency that occurs between 30 and $35 \%$ from the apex. While oscillation frequency was not related to position in the apex, cells more than $30 \%$ from the apex expressed higher frequency oscillations as the base was approached. 
apex which when depolarized with $+50 \mathrm{pA}$ of injected current, oscillated at $190.5 \mathrm{~Hz}$.

Fig. 9 shows an analysis of oscillation frequency versus location on the papilla $(n=20)$. For apical cells the amplitude of injected current which yielded the best resolved oscillations (highest peak to trough ratio) used to measure frequency was between +10 and +30 and for basal cells it was between +20 and $+90 \mathrm{pA}$. The graph shows that cells located in the apical $30 \%$ all show very slow oscillations ranging from about 12 to $23 \mathrm{~Hz}$ and there is no apparent tonotopic organization. On the other hand, cells $35 \%$ or further from the apex show oscillations above $120 \mathrm{~Hz}$ and are organized along the tonotopic axis with respect to oscillation frequency.

\section{Discussion}

Anatomical studies of the chick cochlea have shown variations in hair cell morphology and innervation patterns. For example, there are gradients in the morphology of stereocilia bundles (Tilney and Saunders, 1983) and gradients in the morphology of cell bodies between the two extreme forms, tall hair cells and short hair cells (Hirokawa, 1978; Fischer, 1992). In addition, the pattern of innervation of the basilar papilla changes from the tall hair cells being much more heavily innervated by afferent than efferent fibers, to basal short hair cells that have mostly or only efferent endings (Tanaka and Smith, 1978; Hirokawa, 1978; Manley et al., 1989; Fischer, 1992). Observations of these changes have led to the question of functional variation. For example, the morphological differences of very apical hair cells from the hair cells along the rest of the epithelium have been postulated to reflect a difference in function (Lavigne-Rebillard et al., 1985). Similarly, observations of anatomical variation raise the question of whether the hair cells' phenotypes play a role in auditory frequency selectivity (Hirokawa, 1978).

The issue of peripheral frequency tuning in birds gained indirect support from physiological recordings of the cochlear ganglion, VIIIth nerve fibers, and central nervous system (Rubel and Parks, 1975; Manley, 1979; Manley et al., 1985; Temchin, 1988). These studies demonstrated that the nerve, cochlear ganglion and central terminations are tonotopically organized; a property that could have originated in the cochlea. It was already established that there was mechanical tuning in the chick cochlea with von Békésy's (1960) observations that the basilar membrane optimally vibrated at different frequencies along the length of the papilla. The question remained, however, as to whether avian hair cells are capable of sharpening this tuning through electrical resonance as demonstrated in hair cells of reptiles and amphibians (Crawford and Fettiplace,
1981; Lewis and Hudspeth, 1983; Art and Fettiplace, 1987; Pitchford and Ashmore, 1987; Fuchs and Evans, 1988). Direct evidence for electrical resonance in the chick cochlea was provided by studies of isolated tall hair cells (Fuchs et al., 1988). This resonance is the result of the interaction of the cell's membrane currents. The tonotopy of resonance is thought to be determined by the tonotopy of the magnitudes of these currents. The goal of our studies was to map changes in the outward $\mathrm{K}^{+}$conductances, which are essential to generating electrical resonance in chick tall hair cells (Fuchs and Evans, 1990), in order to get a clearer understanding of how the physiology of tall hair cells changes along the length of the basilar papilla of normal chicks. These data can then be compared with animals in which genetic or environmental manipulations have been made. We think it will be of particular interest to compare the results presented here with similar observations on regenerating hair cells.

\section{1. $K^{+}$currents}

The initial fast activating outward current found in avian tall hair cells is blocked by $\mathrm{Ca}^{2+}$-free solutions, and shows sensitivity to the potassium channel blocker TEA. This initial fast outward current displays kinetics and pharmacology very similar to the calcium-activated potassium current $\left(I_{\mathrm{K}(\mathrm{Ca})}\right)$ as described in dissociated chick tall hair cells (Fuchs et al., 1988; Fuchs and Evans, 1990), isolated chick vestibular hair cells (Ohmori, 1984), turtle auditory (Art et al., 1993) and frog saccular hair cells (Lewis and Hudspeth, 1983).

The slow outward current component, in contrast, is unaffected by $\mathrm{Ca}^{2+}$-free solution, insensitive to TEA but quite sensitive to 4-AP. It is voltage-activated at about $-50 \mathrm{mV}$. The voltage activation, kinetics and pharmacology seem to categorize this current as a delayed rectifier potassium current $\left(I_{\mathrm{K}(\mathrm{DR})}\right)$. Although kinetics and pharmacology vary, $I_{\mathrm{K}(\mathrm{DR})}$ can display slow kinetics (Hille, 1992; Johnston and $\mathrm{Wu}, 1995)$ and relative insensitivity to TEA (Tasaki and Hagiwara, 1957; Stanfield, 1970; Wong and Binstock, 1980). A current bearing properties very similar to $I_{\mathrm{K}(\mathrm{DR})}$ has been reported in dissociated chick hair cells (Fuchs and Evans, 1990) as well as turtle cochlear hair cells (Art et al., 1993).

\subsection{Basilar papilla maps}

When the results of these experiments are mapped along the length of the papilla, several interesting observations are evident. First, the amount of steady-state outward current of tall hair cells increases exponentially from apex to base. There is also a tonotopic increase in the magnitude of $I_{\mathrm{K}}$; however, the rise is not as dra- 
matic. In addition, the subtraction current, which is an approximation of $I_{\mathrm{K}(\mathrm{Ca})}$, also increases in magnitude from apex to base. These results reflect the gradients in the two individual outward $\mathrm{K}^{+}$currents as one travels along the length of the basilar papilla. It can be seen that $I_{\mathrm{K}}$ and $I_{\mathrm{K}(\mathrm{Ca})}$ increase in magnitude as the base of the papilla is approached, resulting in basal hair cells displaying much larger outward currents. This result brings to mind frequency-place maps described in the chick cochlea by a variety of investigators (Manley et al., 1987; Chen et al., 1994; Jones and Jones, 1995; Ryals and Rubel, 1982, 1985a,b). The increase in speed and amplitude of tall hair cells' currents may reflect the increase in frequency that the cells are tuned to from apex to base. Our results, in addition, show that tall hair cells of the apex, which show low-frequency oscillations, as well as hair cells $50-60 \%$ from the apex, which have much higher frequency oscillations, have both $I_{\mathrm{K}}$ and $I_{\mathrm{K}(\mathrm{Ca})}$. In studies of turtle cochlear hair cells it was found that the tonotopy of resonant frequency resulted from variations in the amounts of both $I_{\mathrm{K}(\mathrm{Ca})}$ and $I_{\mathrm{K}}$ (Goodman and Art, 1996b). These results are also consistent with those of Navaratnam et al. (1997) and Rosenblatt et al. (1997) who showed systematic variation in the expression of splice variants of a gene encoding one $I_{\mathrm{K}(\mathrm{Ca})}$ along the length of the papilla.

An unexpected result of this study was the abrupt change in oscillation frequency when mapped against place on papilla. Although the outward currents form a gradient in magnitude, the membrane voltage oscillations were either slow (below $25 \mathrm{~Hz}$ ) or faster (above $120 \mathrm{~Hz}$ ). Cells located in the apical $30 \%$ of the papilla displayed the slow oscillations and the frequency of oscillation did not appear to change tonotopically. Cells located more basal than 35\% from the apex, however, displayed the faster oscillations and these cells were tonotopically organized with respect to frequency. This is a curious result because it raises the question of if and how the membrane voltage oscillations help in electrical tuning and resonance in chick tall hair cells. It also raises the question of what changes at about $35 \%$ along the papilla from the apex to underlie such an abrupt and obvious change in oscillation frequency. One obvious caveat is that these experiments were done at room temperature and therefore, the frequencies recorded would be slower than what would exist in vivo. In addition, an explanted basilar papilla lacks the added tuning afforded to it by the effects of the mechanical tuning of the basilar membrane or stereocilia bundles. Also, the method of stimulation may not be physiological for apical hair cells. High-frequency sounds may produce a DC current in the high-fre- quency tuned basal hair cells while lower frequency sounds may produce a more AC response in the lowfrequency apical hair cells. Therefore, injection of square current pulses may not be a biologically relevant method of stimulating apical hair cells (Eisen et al., 1998). Lastly, it is possible that the currents recorded in this in vitro preparation still may not be of the magnitude of hair cells in vivo. Although the currents recorded here are greater than the currents measured in isolated hair cells and may more accurately depict hair cell physiology, it is still an in vitro preparation and any loss of current will affect the frequency of membrane voltage oscillations.

This study also demonstrates a new preparation where the entire chick basilar papilla is kept intact. The benefits of this preparation are the ability to map the physiology of hair cells along the epithelium to a more detailed degree, as well as minimizing enzymatic treatments. Only collagenase was used to remove the tectorial membrane in these experiments, eliminating the use of isolation enzymes which have been shown to quite dramatically affect recorded currents and membrane voltage oscillations in the frog sacculus (Armstrong and Roberts, 1998). As a result, the currents that were recorded here are considerably greater than the currents that have been reported previously from isolated hair cells (Fuchs and Evans, 1990). Additionally, the magnitude of the individual currents when pharmacologically separated is significantly larger. Therefore, this method of recording from chick hair cells may give a more accurate physiological reflection of the magnitude and distribution of the two outward $\mathrm{K}^{+}$currents. Lastly, this preparation allows for the tonotopic changes in other physiological properties of chick auditory hair cells to be investigated in more detail. For example, the preparation affords one the ability to track differences in currents and voltage responses of hair cells along the superior to inferior axis. This would allow one to study the physiological changes that occur alongside morphological changes as the hair cells move from tall to intermediate to short hair cells. In addition, it also may allow for the study of hair cells during various manipulations of the cochlea where the basilar papilla needs to be intact, such as hair cell damage and regeneration.

\section{Acknowledgements}

The authors are grateful to Dr. Paul Fuchs and Dr. Cecilia Armstrong for critically reading and commenting on the manuscript. The research was supported by NIH/NIDCD Grant DC00395. 


\section{References}

Armstrong, C.E., Roberts, W.M., 1998. The electrical properties of frog saccular hair cells: Distortion by enzymatic dissociation. J. Neurosci. 18, 2962-2973.

Art, J.J., Fettiplace, R., 1987. Variation of membrane properties in hair cells isolated from the turtle cochlea. J. Physiol. 385, 207-242.

Art, J.J., Fettiplace, R., Wu, Y.C., 1993. The effects of low calcium on the voltage-dependent conductances involved in tuning of turtle hair cells. J. Physiol. 470, 109-126.

Chen, L., Salvi, R., Shero, M., 1994. Cochlear frequency-place map in adult chickens: intracellular biocytin labeling. Hear. Res. 81, $130-136$.

Crawford, A.C., Fettiplace, R., 1981. An electrical tuning mechanism in turtle cochlear hair cells. J. Physiol. 306, 79-125.

Eisen, M.D., Saunders, J.C., Parsons, T.D., 1998. High frequency mechanoelectric transduction by individual chick cochlear tall hair cells. Assoc. Res. Otolaryngol. 21, 1998.

Fischer, F.P., 1992. Quantitative analysis of the innervation of the chicken basilar papilla. Hear. Res. 61, 167-178.

Fuchs, P.A., Evans, M.G., 1988. Voltage oscillations and ionic conductances in hair cells isolated from the alligator cochlea. J. Comp. Physiol. A 164, 151-163.

Fuchs, P.A., Evans, M.G., 1990. Potassium currents in hair cells isolated from the cochlea of the chick. J. Physiol. 429, 529-552.

Fuchs, P.A., Evans, M.G., Murrow, B.W., 1990. Calcium currents in hair cells isolated from the cochlea of the chick. J. Physiol. 429, 553-568.

Fuchs, P.A., Nagai, T., Evans, M.G., 1988. Electrical tuning in hair cells isolated from the chick cochlea. J. Neurosci. 8, 2460-2467.

Fuchs, P.A., Sokolowski, B.H., 1990. The acquisition during development of Ca-activated potassium currents by cochlear hair cells of the chick. Proc. R. Soc. Lond. Biol. Sci. 241, 122-126.

Goodman, M.B., Art, J.J., 1996a. Positive feedback by a potassiumselective inward rectifier enhances tuning in vertebrate hair cells. Biophys. J. 71, 430-442.

Goodman, M.B., Art, J.J., 1996b. Variations in the ensemble of potassium currents underlying resonance in turtle hair cells. J. Physiol. 497, 395-412.

Hamill, O.P., Marty, A., Neher, E., Sakmann, B., Sigworth, F.J., 1981. Improved patch-clamp techniques for high-resolution current recordings from cells and cell-free membrane patches. Pflug. Arch. 391, 85-100.

Hille, B., 1992. Ionic Channels of Excitable Membranes. Sinauer, Sunderland, pp. 74-78.

Hirokawa, N., 1978. The ultrastructure of the basilar papilla of the chick. J. Comp. Neurol. 181, 361-374.

Johnston, D., Wu, S.M.-S., 1995. Foundations of Cellular Neurophysiology. The MIT, Cambridge, MA, p. 198.

Jones, S.M., Jones, T.A., 1995. The tonotopic map in the embryonic chicken cochlea. Hear. Res. 82, 149-157.

Lavigne-Rebillard, M., Cousillas, H., Pujol, R., 1985. The very distal part of the basilar papilla in the chicken: A morphological approach. J. Comp. Neurol. 238, 340-347.

Lewis, R.S., Hudspeth, A.J., 1983. Voltage- and ion-dependent conductances in solitary vertebrate hair cells. Nature 304, 538-540.

Manley, G.A., 1979. Preferred intervals in the spontaneous activity of primary auditory neurons. Naturwissenshaften 66, 582-584.

Manley, G.A., Gleich, O., Kaiser, A., Brix, J., 1989. Functional differentiation of sensory cells in avian auditory periphery. J. Comp. Physiol. A 164, 289-296.

Manley, G.A., Gleich, O., Leppelsack, H.-J., Oekinghaus, H., 1985. Activity patterns of cochlear ganglion neurons in the starling. J. Comp. Physiol. A 157, 161-181.
Manley, G.A., Brix, J., Kaiser, A., 1987. Developmental stability of the tonotopic organization of the chick's basilar papilla. Science 237, 655-656.

Martinez-Dunst, C., Micheals, R.L., Fuchs, P.A., 1997. Release sites and calcium channels in hair cells of the chick's cochlea. J. Neurosci. 17, 9133-9144.

Navaratnam, D.S., Bell, T.J., Tu, T.D., Cohen, E.L., Oberholtzer, J.C., 1997. Differential distribution of $\mathrm{Ca}^{2+}$-activated $\mathrm{K}^{+}$channel splice variants among hair cells along the tonotopic axis of the chick cochlea. Neuron 19, 1077-1085.

Ohmori, H., 1984. Studies of ionic currents in the isolated vestibular hair cell of the chick. J. Physiol. 350, 561-581.

Pantelias, A.A., Monsivais, P., Rubel, E.W., 1998. Tonotopic map of current and voltage responses of chick auditory hair cells using an intact basilar papilla preparation. Assoc. Res. Otolaryngol. 20, 21.

Pitchford, S., Ashmore, J.F., 1987. An electrical resonance in hair cells of the amphibian papilla of the frog Rana temporaria. Hear. Res. 27, 75-83.

Rebillard, G., Rubel, E.W., 1981. Electrophysiological study of the maturation of auditory responses from the inner ear of the chick. Brain Res. 229, 15-23.

Rosenblatt, K.P., Sun, Z.P., Helly, S., Hudspeth, A.J., 1997. Distribution of $\mathrm{Ca}^{2+}$ activated $\mathrm{K}^{+}$channel isoforms along the tonotopic gradient of the chicken cochlea. Neuron 19, 1061-1075.

Rubel, E.W., Parks, T.N., 1975. Organization and development of brain stem auditory nuclei of the chicken: tonotopic organization of n. magnocellularis and n. laminaris. Comp. Neurol. 164, 411433.

Ryals, B.M., Rubel, E.W., 1982. Patterns of hair cell loss in chick basilar papilla after intense auditory stimulation. Frequency organization. Acta Otolaryngol. 93, 205-210.

Ryals, B.M., Rubel, E.W., 1985a. Differential susceptibility of avian hair cells to acoustic trauma. Hear. Res. 19, 73-84.

Ryals, B.M., Rubel, E.W., 1985b. Ontogenetic changes in the position of hair cell loss after acoustic overstimulation in avian basilar papilla. Hear. Res. 19, 135-142.

Saunders, J.C., Coles, R.B., Gates, G.R., 1973. The development of auditory evoked responses in the cochlea and cochlear nuclei of the chick. Brain Res. 63, 59-74.

Stanfield, P.R., 1970. The effect of the tetraethylammonium ion on the delayed currents of frog skeletal muscle. J. Physiol. 209, 209-229.

Takasaka, T., Smith, C.A., 1971. The structure and innervation of the pigeon's basilar papilla. J. Ultrastruct. Res. 35, 20-65.

Tanaka, K., Smith, C.A., 1978. Structure of the chicken's inner ear: SEM and TEM study. Am. J. Anat. 153, 251-272.

Tasaki, I., Hagiwara, S., 1957. Demonstration of two stable potential states in the squid giant axon under tetraethylammonium chloride. J. Gen. Physiol. 40, 859-885.

Temchin, A.N., 1988. Unusual discharge patterns of single fibers in the pigeon's auditory nerve. J. Comp. Physiol. A 163, 99-115.

Tilney, L.G., Saunders, J.C., 1983. Actin filaments, stereocilia, and hair cells of the bird cochlea. I. Length, number, width, and distribution of stereocilia of each hair cell are related to the position of the hair cell on the cochlea. J. Cell Biol. 96, 807-821.

Tucci, D.L., Rubel, E.W., 1990. Physiological status of regenerated hair cells in the avian inner ear following aminoglycoside ototoxicity. Otolaryngol. Head Neck Surg. 103, 443-450.

von Békésy, G., 1960. Experiments in Hearing. McGraw-Hill, New York.

Wong, B.S., Binstock, L., 1980. Inhibition of potassium conductance with external tetraethylammonium ion in Myxicola giant axons. Biophys. J. 32, 1037-1042. 